\title{
Observance of the Written Form of a Transaction Made by Electronic or Other Technical Means
}

\author{
Igor Mashtakov ${ }^{1, *}$ Lyudmila Starodubova ${ }^{1}$ Olga Lapshina ${ }^{1}$ \\ ${ }^{1}$ Togliatti State University, Togliatti 445020, Russian Federation \\ *Corresponding author. Email: zavet4@ rambler.ru
}

\begin{abstract} civil transactions. equivalence.

\section{INTRODUCTION}

The current civil legislation of the Russian Federation establishes the possibility of making civil transactions using electronic data exchange. Thus, the subjects of civil relations find for themselves a new way of participating in them. This method is closely related to the new method of transferring and storing information.
\end{abstract}

The legal regulation of transactions made with the help of electronic or technical means does not have a structured, generalized and clear regulatory framework for a free understanding. Moreover, the practical use of this method of concluding civil transactions is ahead of their legal regulation, which cannot but give rise to corresponding problems both in the theory of civil transactions and in judicial practice. On the one hand, the use of information networks when concluding and executing transactions to some extent complicates public relations, but on the other hand, it simplifies the very organizational procedure for formalizing, for example, contractual relations, and shortens the process of entering into legal force in time. Nevertheless, this raises the problem of determining the moment of such a transaction, as well as the problem of maintaining the integrity of the transmitted information and its certification.

The purpose of the study is to determine the legal essence and identify the main problems of the application of transactions made using electronic or other technical means, study the features of the legal regulation of such transactions, the practice of applying these norms based on Russian and foreign legislation, develop recommendations for improving civil legislation in this area, determination of the possibility of using electronic data exchange in the performance of certain

When writing this article, both general scientific and specific scientific research methods were used: historical-legal, logical-legal, linguistic, complex, methods of analogy, comparative jurisprudence, as well as the systemic methods.

Keywords: Electronic transaction, electronic document, electronic signature, data exchange, certification of

In this regard, a special information environment presupposes the execution of such transactions in an unconventional way, in contrast to the preparation of a single document on paper or the exchange of such documents. It is no accident that in civil and business relations both in the Russian Federation and at the international level, such phrases as "electronic commerce" and "electronic commerce" have taken root and found their practical application. In international practice, this is facilitated by global communication networks, and in the Russian Federation, based on the experience of, first of all, European countries, modern technologies are being introduced that facilitate the electronic exchange of data between the parties to the transaction.

There is a plethora of research devoted to the civil law research of information exchange relations, the conclusion of transactions in the global computer net- work "Internet". The civil-legal regulation of electronic transactions, e-commerce, transactions in electronic information networks, the use of electronic documents in contractual relations become very important topics nowadays.

Special attention to the legal nature of the electronic form of transactions, the peculiarities of the electronic form of banking transactions is given in the scientific works of Efimova [1]. In the foreign literature, such foreign scientists as Denizot [2], Kablan [3], Ethan [4], Mason and Reiniger [5], and Chou [6].

Securing in civil law the possibility of making civil transactions made using electronic or other technical means implies subsequent clarifications, primarily by law enforcement agencies, of the relevant categories: "electronic means", "technical means" and "reproduction on a tangible medium." Mentioning such terms and phrases in various Russian regulations, including the subordinate level, international legal acts does not solve the problem of a single interpretation and clear understanding of the legal procedure for making so-called electronic transactions. With regard to the entry of a civil law transaction into legal force, as well as the conclusion of a civil law contract, it is necessary to regulate the moment from which unilateral transactions and contracts will be considered concluded (completed) using electronic and technical means. To resolve this issue, it 
is necessary to adjust the ratio of such concepts as "electronic message", "electronic document", "electronic data interchange", etc. The concepts of "will", "offer" and "acceptance", traditional for civil transactions and contracts, require the development of special rules of civil legislation on the electronic method of establishing, changing and terminating civil rights and obligations.

Our paper structured as follows: Section 2 is divided into four subsections, which sequentially consider "The concept of an "electronic transaction", its main characteristics and features of legal regulation, "Features of the conclusion of" electronic transactions "and their entry into legal force", "Some sources of Russian and international legal regulation electronic document management "and" Problems of transactions concluded using electronic and technical means". Section 3 contains the final conclusions confirming the relevance of the problems highlighted in this scientific article, which are the subject of research not only by domestic authors, but also by scientists from foreign countries on the basis of, first of all, European legislation.

\section{RESEARCH BACKGROUND}

Electronic transactions in the Russian Federation are not entirely new. In this regard, in the legal literature of the 1990s, one can find a definition of the concept of such an activity as "electronic commerce". E-commerce is a set of issues arising in connection with all relationships of a commercial nature, which include (but are not limited to) the following transactions: purchase and sale, supply, distribution agreement, port representative or agency, factoring, leasing, design, consulting, engineering, investment contracts, insurance, operation and concession agreements, banking services, joint activities and other forms of industrial and business cooperation, transportation of goods or passengers by air, sea, rail. In international legal acts this phrase was also used. In foreign literature, in relation to contractual relations placed in a digital environment, it is proposed to use the term "dematerialization", that is, when it is possible to abandon the use of paper media in the contractual relationship of the parties and create a new paperless information environment, which allowed French legal literature to express this about nothing other than "adieu au papier" [2, pp. 233-234]. This idea was expressed even earlier by such a European scientist as Kablan, he believes that "information in cyberspace always receives a computer expression, which is usually digital or analog" [3, p. 116].

Thus, if there is such an activity as electronic commerce, first of all, in the economic sense of the word, then we should talk about the so-called "electronic transactions", giving them a legal meaning.
In the current Civil Code of the Russian Federation [7], such transactions are interpreted in Art. 160 through the observance of their written form by "a person completing a transaction using electronic or other technical means that make it possible to reproduce the contents of the transaction on a material medium unchanged, while the requirement for a signature is considered fulfilled if any method is used that allows one to reliably identify the person who expressed will" [8]. Thus, this rule of the Civil Code of the Russian Federation will work provided that it is possible:

- Reproduce the content of the transaction unchanged on a tangible medium (for example, print it on paper);

- To reliably identify contractors.

The written form of the transaction is more familiar to a Russian participant in civil legal relations as a paper document. And here, if the transaction is made using electronic means, then, apparently, we should talk about some kind of electronic document. The Federal Law "On Information, Information Technologies and Information Protection" [9] discloses the concept of "electronic document" as "documented information presented in electronic form, that is, in a form suitable for human perception using electronic computers, as well as for transmission over information and telecommunication networks or processing in information systems" (clause 11.1 of article 2).

In this regard, the opinion is expressed in the legal literature that "An electronic document in the form of a computer program should be considered an electronic dynamic hypertext document. It is fundamentally different from a document in traditional writing, which makes it possible to substantiate the independence of the electronic form of the transaction, its irreducibility to the usual writing". But, if on paper the written form of the transaction presupposes the signatures of its parties in the traditional sense, then the electronic document should be closely related to the concept of "electronic signature". In accordance with the Federal Law "On Electronic Signature"[10], an electronic signature is "information in electronic form that is attached to other information in electronic form (information to be signed) or otherwise associated with such information and which is used to identify the person signing information" (clause 1, article 2).

Some clarifications on this matter are also given by the Supreme Court of the Russian Federation in relation to the activities of courts of general jurisdiction and arbitration courts: "an electronic document is a document created in electronic form without preliminary documentation on paper, signed with an electronic signature in the manner prescribed by the legislation of the Russian Federation; electronic signature - information 
in electronic form, attached to the signed electronic document or otherwise associated with it and allowing to identify the person who signed the electronic document" [11]. These clarifications of the Supreme Court of the Russian Federation correspond to the Decision of the Board of the Eurasian Economic Commission, where in clause 1.6.1. Of the Regulations of the Certification Center, an electronic document is defined as "an electronic document certified by an electronic digital signature (electronic signature) and meets the requirements of the general infrastructure for documenting information in electronic form", and an electronic digital signature (electronic signature) as "EDS - information in electronic form, which is attached to other information in electronic form or is otherwise related to such information, serves to control the integrity and authenticity of this information, ensures the impossibility of repudiation, is generated by applying a cryptographic transformation with respect to this information using a private (personal) key (EDS key ) and verified using the public key (EDS verification key)" [12]. Thus, a person does not physically sign anything, but uses a computer program to sign a document electronically. The signature serves to identify the person of the signer and to confirm the authenticity of the document. Another foreign researcher, Professor Chou adheres to the same position, he writes: "This is important because the act of signing using an electronic signature has a different symbolic meaning than the signature of a manuscript, and suggests a weaker sense of human involvement in the signing process" [6].

\section{ELECTRONIC TRANSACTIONS' EN- TRY INTO LEGAL FORCE}

If we carry out the traditional division of civil law transactions into unilateral and bilateral (multilateral) and apply the new rule of the Civil Code of the Russian Federation on electronic transactions, one involuntarily wonders whether the way of expressing will as a necessary element of it matters for an electronic transaction. If for the traditional simple written form of the transaction the will can be expressed both orally and in writing, then for the electronic form of the transaction the way of expressing the will can only be "electronic", that is, using electronic or other technical means, if any method is used that allows reliable determine the person who has expressed the will. In this regard, in civil law, in our opinion, it will be necessary to reveal in more detail the possible ways of expressing the so-called "electronic expression of will". On this occasion, back in 1995, such a foreign scientist as Ethan wrote, who argued about a computer program not only as a way of fixing the will of the parties, but also argued that "an electronic agreement binds the parties to each other and, if desired, to other people, as well as with various sources of information (databases) in ways that are difficult to represent with the help of paper" $[4,125 \mathrm{p}$.].

In our opinion, the solution of this issue is of particular interest when concluding, first of all, unilateral transactions, since the expression of will on only one side, which will be enough for the transaction to enter into legal force, will not take into account the counter expression of will that we observe in contracts (bilateral and multilateral transactions). So, in accordance with paragraph 2 of Art. 434 of the Civil Code of the Russian Federation: "An agreement in writing can be concluded by drawing up one document (including electronic) signed by the parties, or by exchanging letters, telegrams, electronic documents or other data ...". As rightly noted in his time Melnikov, "a new method of concluding contracts requires the introduction of some new rules concerning the procedure for proving, the existence of contractual relations, the procedure for certifying the content of a document using special technical means, as well as a number of new rules on concluding contracts, etc." [13, 12 p.].

Moreover, the compilation of an electronic document, the exchange of electronic documents requires an explanation in civil law, in what ways of expressing the expression of will in electronic form, an electronic document can be considered compiled, and the exchange of electronic documents is valid. On this occasion, there is a small explanation in paragraph 4 of Art. 11 of the Federal Law "On Information, Information Technologies and Information Protection": "In order to conclude civil law contracts or formalize other legal relations in which persons exchanging electronic messages participate, the exchange of electronic messages, each of which is signed with an electronic signature or other equivalent the handwritten signature of the sender of such a message, in the manner prescribed by federal laws, other regulatory legal acts or by agreement of the parties, is considered an exchange of documents. " It is clear that such a clarification cannot be enough, since it becomes not entirely clear what content an electronic message should be in order to have the status of an electronic document and, accordingly, whether any exchange of electronic messages should be recognized as an exchange of documents. In fact, to date, civil legislation operates only with general definitions in the field of electronic document management without reference to specific practical situations that can claim a legal procedure for concluding (making) civil law transactions in writing using electronic or other technical means. 


\section{RUSSIAN AND INTERNATIONAL LE- GAL REGULATION OF ELECTRONIC DOCUMENT MANAGEMENT}

The above and other individual federal laws, of course, come to the aid of the Civil Code of the Russian Federation, explaining the rules of electronic document flow in relation to a specific area of economic and entrepreneurial activity. For example, in Art. 6.1. Of the Law of the Russian Federation "On the organization of insurance business in the Russian Federation" [14] discusses the features of the exchange of information in electronic form between the policyholder and the insurer. Creation and sending of information by the insured (insured person, beneficiary) to the insurer in electronic form for the conclusion, modification, early termination of the insurance contract, in order to receive insurance payment in the cases and in the manner provided for by the insurance rules, are carried out using the official website of the insurer in the information and telecommunication the Internet. In this case, the specified official website of the insurer can be used as an information system that ensures the exchange of information in electronic form between the policyholder and the insurer, which is the operator of this information system. When carrying out voluntary insurance, information in electronic form sent to the insurer and signed by a simple electronic signature of the policyholder (insured person, beneficiary) is recognized as an electronic document equivalent to a paper document signed by the personal signature of this individual, unless otherwise provided by the insurance rules.

Another example of special requirements for electronic document flow is contained in the Fundamentals of the Legislation of the Russian Federation on Notaries [15], which provide for certification of the equivalence of an electronic document to a paper document or, conversely, a paper document to an electronic one. Such certification is carried out by a notary (Articles 103.8, 103.9) [16]. An electronic document produced by a notary has the same legal force as a paper document, the equivalence of which is certified by a notary. The production of an electronic document to certify its equivalence to a document on paper is carried out by a notary by making an electronic image of the document on paper and signing it with a qualified electronic signature of the notary. An electronic image of a document on paper is formed as a single image file in PDF format. A notarized document must be scanned with a resolution of $200 \mathrm{dpi}$ (dots per inch) in grayscale, with a color depth of 8 bits per pixel. The generated file of an electronic document, which is an electronic image of a document, includes a certification inscription made by a notary in electronic form. An electronic image of a document containing an attestation inscription is signed with an enhanced qualified electronic signature of a notary [17]. Such certification of equivalence may be required, for example, when preparing the parties for a transaction. In this regard, "innovations in the field of electronic notaries make it possible to increase the degree of security of participants in all transactions certified by a notary in electronic form. Also, electronic certification of transactions can significantly reduce the cost of registration of the transaction, reducing them several times compared to the cost of services of real estate companies" [18, pp. 20-21]

In addition, the legal literature expresses the idea of "the concept of quasi-notary transactions, which are concluded in a simple written form with notification registration by a notary appointed by the parties through the latter maintaining a special register of electronic messages with attached files containing signed originals of civil law contracts (agreements, etc.)" [19, 16 p.].

The exchange of electronic documents as a legalized written form of concluding a contract must have evidentiary force in court. Therefore, in accordance with paragraph 3 of Art. 75 of the APC RF [20] "Documents received through facsimile, electronic or other communication, including using the information and telecommunications network" Internet ", as well as documents signed with an electronic signature in the manner prescribed by the legislation of the Russian Federation are allowed as written evidence" [21].

If any written document is characterized by the possibility of further use, then the same possibility should be provided for an electronic document. Thus, according to the UN Convention "On the Use of Electronic Communications in International Agreements" [22], in cases where legislation requires that a message or agreement be submitted in writing, or provides for the occurrence of certain consequences in the absence of a written form, this requirement is considered fulfilled by submission of an electronic message, if the information contained therein is available for its subsequent use (clause 2, article 9).

\section{IMPLEMENTATION OF TRANSAC- TIONS USING ELECTRONIC AND TECHNICAL MEANS}

If in art. 160 and 434 of the Civil Code of the Russian Federation provides for the possibility of concluding electronic transactions and agreements, in the same way you can talk about their execution, amendment and termination using electronic data exchange. As it was rightly noted in the legal literature, "when using electronic means, the legal essence of a transaction does not change as an action aimed at establishing, changing or terminating civil rights and obligations" [23, 34 p.].

The traditional definition of an obligation in the civil legislation of the Russian Federation (clause 1 of article 307 of the Civil Code of the Russian Federation) 
involves, first of all, the performance of a certain action:

- Transfer property;

- Do the job;

- Provide service;

- To contribute to joint activities;

- Pay money, etc.

If the fixation of the fact of the conclusion of a unilateral transaction or agreement, on the basis of which the obligation arose, occurred using electronic and technical means, then the fixation of the fact of execution of such a transaction or agreement may proceed according to the same scenario. The execution of such contracts that are practically significant for the national economy such as supply, energy supply, retail purchase and sale, sale of real estate (enterprise), contract, paid services, etc. can, in principle, be accompanied not by paper documents, but by fixing such a fact of execution in a computer program. Assuming the existence of an electronic document in the form of a computer program. It can be rightly pointed out that the computer program does not just record the will of the parties. In addition to this function, the program monitors the development of relations between the parties before and after the conclusion of the contract, reacts to new events, records the performance of the contract or initiates its execution, provides the parties with additional information, records changes in conditions contracts and performs other actions.

Electronic recording, including in a computer program, may be subject to such known grounds for changing or terminating the contract, such as an agreement of the parties, a material violation of the terms of the contract by the other party, a significant change in circumstances, cancellation of the contract (performance of the contract) or the exercise of rights under the contract. In the same Art. 450.1 of the Civil Code of the Russian Federation refers to the observance of a mandatory notification procedure, which in its essence already begs for the possibility of implementation using electronic and technical means. When fixing the grounds and procedure for changing or terminating the contract, the parties proceed from the fact that the agreement to amend or terminate the contract is made in the same form as the contract (clause 1 of article 452 of the Civil Code of the Russian Federation).

\section{CONCLUSIONS}

The Civil Code of the Russian Federation today takes a very controversial position in the legal scientific community regarding the legal nature of transactions concluded using electronic and technical means. Some scientists put forward quite convincing arguments indicating the need to recognize the electronic form of the transaction as an independent one, different from the written form. Nevertheless, the arguments of the researchers on this issue, which indicate the possibility of the existence of only an electronic form of a document, but not a transaction, deserve attention. The position of the author of this article is still on the side of the legislator and is dictated by the need to further improve legal regulation, taking into account the borrowing of the best practices of European countries on this issue.

In scientific research of the presented topic, it has long been proposed to adopt a law "On electronic commerce", which would reveal the concept of an electronic transaction [24, 141 p.]. Researchers on this topic are also very concerned about the risks involved in concluding electronic transactions, including via the Internet. It is proposed to use the mechanisms developed by judicial practice to prove the existence of contractual relations such as: negotiations by e-mail, systematic document flow in electronic form, indication of e-mail addresses from the domain of counterparties in the contract, implicit actions of the parties on the actual execution of the contract or subsequent approval of the transaction [25, pp. $213-214]$. The authors of scientific publications on the legal regulation of electronic transactions note the shortcomings of the practical application of the provisions of the Russian legislation on electronic digital signature, in connection with which it is proposed to use in this area the legislative experience of Germany on the creation and regulation of certification centers [26, 27], taking into account that in Germany, the corresponding law has been in effect since December 21,2001 . It appears that it would be very beneficial for all involved parties to apply the same legal provisions in the Russian Federation as well.

\section{REFERENCES}

[1] L.G. Efimova, On the Concept and Legal Nature of the Electronic Form of the Transaction, Lex Russica 8 (2019) $129-137 . \quad$ DOI: $17803 / 1729$ 5920.2019.153.8.129-137

[2] A. Denizot, Chroniques 1-er octobre - 312017 , RTDCiv. trimestrielle de droit civil Janvier - mars (2018) 560.

[3] S. A. Kablan, Pour une évolution du droit des contrats: le contrat électronique et les agents intelligents, Thèse présentée à la Faculté des études supérieures de l'Université Laval dansl ecadre du programme de doctorat en droit pour l'obtention du grade de docteur en droit (LL.D.), Faculté de droit, Université Laval Québec, 2008, pp. 116-122. 
[4] K.M. Ethan, Law in a Digital World, Oxford University press, 1995, $334 \mathrm{p}$.

[5] S. Mason, T.S. Reiniger, "Trust" between machines? Establishing identity between humans and software code, or whether you know it is a dog, and if so, which dog? Computer and Telecommunications Law Review 21 (2015) 135-48.

[6] E.Y. Chou, Paperless and soulless: e-signatures diminish the signer's presence and decrease acceptance, Social Psychological and Personality Science 6(3) (2015) 343-51. DOI: https://doi.org/10.1177/1948550614558841

[7] Civil Code of the Russian Federation (part one) of November 30, 1994 No. 51-FZ (as amended on July 18, 2019) (as amended and supplemented, entered into force on October 1, 2019) // SZ RF. 1994. No. 32. Art. 3301.

[8] Federal Law of 18.03.2019 No. 34-FZ "On Amendments to Parts One, Two and Article 1124 of Part Three of the Civil Code of the Russian Federation" // SZ RF. 2019. No. 12. Art. 1224

[9] Federal Law of 27.07.2006 No. 149-FZ (as amended on 02.12.2019) "On information, information technologies and information protection" // SZ RF. 2006. No. 31 (1 hour). Art. 3448.

[10] Federal Law of 06.04.2011 No. 63-FZ (as amended on 23.06.2016) "On electronic signature" (as amended and supplemented, entered into force on 31.12.2017) // SZ RF. 2011. No. 15. Art. 2036.

[11] Resolution of the Plenum of the Supreme Court of the Russian Federation of December 26, 2017 No. 57 "On some issues of the application of legislation governing the use of documents in electronic form in the activities of courts of general jurisdiction and commercial courts" // Bulletin of the Supreme Court of the Russian Federation. - 2018. - No. 4.

[12] Decision of the Board of the Eurasian Economic Commission dated 09.07.2018 No. 110 "On the certification center of the Eurasian Economic Commission" (together with the "Regulation on the certification center of the Eurasian Economic Commission"). http://www.eaeunion.org/ Accessed 10 Aug 2019

[13] V.S. Melnikov, Sdelki v elektronnykh kompyuternykh setyakh kak predmet pravovogo regulirovaniya v Rossiyskoy Federatsii, Rossiyskiy sudya 11 (2010) 11-14.

[14] Federal Law of 04.06.2014 No. 149-FZ "On Amendments to the Law of the Russian Federation" On the Organization of Insurance in the Russian Federation "and Certain Legislative Acts of the Russian Federation" // SZ RF. 2014. No. 23. Art. 2934.

[15] Fundamentals of the legislation of the Russian Federation on notaries (approved by the RF Armed Forces on 11.02.1993 No. 4462-1) (as amended on 26.07.2019) (as amended and supplemented, entered into force on 25.10.2019) // Vedomosti SND and VS RF. 1993. No. 10. Art. 357.

[16] Federal Law No. 379-FZ of December 21, 2013 (as amended on July 3, 2016) "On Amendments to Certain Legislative Acts of the Russian Federation" (as amended and supplemented, entered into force on 01.01.2017) // SZ RF. 2013. No. 51. Art. 6699.

[17] Order of the Ministry of Justice of Russia dated June 29, 2015 No. 155 "On approval of the requirements for the format of an electronic document prepared by a notary" (together with the "Requirements for the format of an electronic document prepared by a notary", approved by the Decision of the Board of the Federal Tax Service on June 10, 2015, Order of the Russian Ministry of Justice dated June 29, 2015 No. 155) (Registered in the Ministry of Justice of Russia on June 30, 2015 No. 37827). http://www.pravo.gov.ru Accessed 3 Jul 2015.

[18] A.S. Imansu, Udostoverenniye sdelok v elektronnom vide, Notarius 6 (2017) 20-21.

[19] A.V. Danilenkov, Kvazinotarialnaya forma elektronnykh sdelok, Notarius 6 (2017) 15-19.

[20] The Arbitration Procedure Code of the Russian Federation of July 24, 2002 No. 95-FZ (as amended on November 12, 2019) // SZ RF. 2002. No. 30. Art. 3012.

[21] Federal Law of 23.06.2016 No. 220-FZ "On Amendments to Certain Legislative Acts of the Russian Federation Regarding the Application of Electronic Documents in the Activities of Judicial Authorities" // SZ RF. 2016. No. 26 (Part I). Art. 3889.

[22] United Nations Convention on the Use of Electronic Communications in International Contracts (New York, 23.11.2005) https://www.un.org/ru/documents/decl_conv/conventio ns/elect_com.shtml Accessed 9 Dec 2019

[23] E.A. Shelepina, Primeneniye elektronnykh dokumentov v grazhdanskikh pravootnosheniyakh: usloviya I vozmozhnosti, Zakony Rossii: opyt, analiz, praktika 10 (2017) 31-39.

[24] A.S. Kosarev, Problemy pravovogo regulirovaniya sdelok v sfere elektronnoy kommertsii, Ph.D. Thesis, RANEPA, 2010, 159 p. 
[25] I.A. Shashkova, Civil law regulation of electronic transactions, Civil legislation: current state, trends and development prospects, in: Proceeding of the $4^{\text {th }}$ AllRussian Scientific and Practical Conference, KSAU, Krasnodar, 2019, pp. 209-214.

[26] A.R. Kusaeva, Comparative Analysis of Peculiarities of Electronic Transactions Conclusion in Russia and Germany: Legal Aspects, Vestnik Povolzhskogo instituta upravleniya 19(4) 24-28. DOI: https://doi.org/10.22394/1682-2358-2019-3-24-28

[27] Gesetz über rechtliche Rahmenbedingungen für den elektronischen Geschäftsverkehr) Vom 14.12.2001, verkündet in BGBl I Jahrgang 2001 Nr. 70 vom 20.12.2001. 